\title{
20. Yüzyılda Osmanlı Toprakları Üzerinde Kurulan Nişantaşı İngiliz Erkek Mektebi Üzerine Bir Değerlendirme
}

\author{
An Evaluation of Nişantaşı English Boys School, Founded on Ottoman \\ Lands in the 20th Century
}

\author{
Abdullah KARA* \\ Mustafa ÇAVDAROĞLU**
}

$\ddot{O} \mathbf{z}$

Yabancı okullar, Osmanlı devletinde Avrupalılara ticari alanda ayrıcalıklar verilmesi ve zamanla bu ayrıcalıkların kalıcı olması neticesinde açılma imkânı bulmuşlardır. Osmanlı topraklarında faaliyet gösteren yabancı okullar ilk olarak Fransızlar daha sonra ise İngilizler tarafından açılmışlardır. Daha önce İstanbul İngiliz Erkek Lisesi ile ilgili, Metin Ünver “Osmanlı Devletinde 'ki İngiliz Ticaretinin Almanya karşısında gerilemesi tartışmaları bağlamında İstanbul'da İngiliz Erkek Lisesinin kuruluşu” adlı çalışma ile Osmanlı toprakları üzerinde yabancı devletlerin ekonomik anlamda nüfuz sahibi olabilmek için rekabet aracı olarak açılan okullar bağlamında değerlendirmiştir. Bu çalışmada ise konumuzun temelini teşkil eden Nişantaşı İngiliz Erkek Mektebi adlı çalışmanın orijinali olan "Zükura Mahsus Ingiliz Mektebi" başlıklı Osmanlıca belge bağlamında okulun açılışı, öğrenci kabul şartları, yapısı, okul teşkilatı ve öğretilen dersler, ders içerikleri gibi bilgileri verip bu bilgiler değerlendirilmeye çalışılmıştır. Bu bilgiler Başbakanlık Osmanlı arşivinde konu ile ilgili arşiv belgeleri ile desteklenmiştir. Bu çalışma ile eğitim tarihi alanında yapılan çalışmalara katkıda bulunmak amaçlanmıştır.

Anahtar Kelimeler: Eğitim Tarihi, Yabancı Okullar, Nişantaşı Erkek Lisesi.

\begin{abstract}
Foreign schools had the opportunity to open as a result of the fact that the Europeans were given commercial privileges in the Ottoman state and these privileges became permanent over time. Foreign schools operating in the Ottoman lands were first opened by the French and then the British. Metin Ünver, with the study titled "The establishment of the English Boys' High School in Istanbul in the context of the debates on the decline of British Commerce in the Ottoman State against Germany", was previously related to the Istanbul British Boys' High School. He evaluated it in the context of schools opened as a means of competition for foreign states to have economic influence on the Ottoman lands. In this study, in the context of the Ottoman document titled "Zükura Mahsus İngiliz Mektebi", which is the original of the study called Nişantaşı English Boys School, which forms the basis of our subject, information such as the opening of the school, student admission conditions, structure, school organization and the lessons taught, the course contents were tried to be evaluated. This information was supported by archive documents related to the subject in the Ottoman archive of the Prime Ministry. With this study, it is aimed to contribute to the studies in the field of education history.
\end{abstract}

Keywords: Educatıon History, Foreıgn Schools, Nisantasi Boys High School.

\section{Giriş}

Osmanlı Devleti topraklarındaki yabancı okullar, "İmtiyâzât-1 Ecnebiyye", yani "kapitülasyonlar" adı altında verilen tavizler neticesinde açılma imkânı bulmuşlardır. (İhsanoğlu, 1999, s.358) Daha çok ticari alanda verilen bu ayrıcalıklar, zamanla haklara dönüşerek dini, siyasi ve sosyal alanlarda da yaygınlaşmış ve bu durum eğitim alanında da devam etmiştir. (Sezer, 1999, s.7) Osmanlı devletinin en güçlü olduğu dönemlerde, gücün bir simgesi olarak tek taraflı olarak verilen kapitülasyonlar, ilk olarak Kanun-i Sultan Süleyman tarafindan, Fransa Kralı François'ya verilmiştir. Kendisine tanınan bu ayrıcalıklardan yararlanan Fransız kralı, Cizvitlerin İstanbul'a gelmesini ve burada bir okul açmalarını sağlamıştır. Cizvitler ${ }^{1}$, 18 Kasım 1583'te İstanbul Galata'da bulunan Saint Benoit Kilisesine

\footnotetext{
*Dr., Abdullahkara01@ gmail.com

** Uzman, ensarenes61@ gmail.com

1 “Geleneksel Hristiyanlık anlayışının yanı sıra bu anlayışı günün şartlarına göre şekillendiren reform hareketi Katolikliğe yeni bir düzen kazandırarak 15 Ağustos 1534 yılında kurulmuş olan Hristiyan tarikatıdır.” Ayrıntılı bilgi için Bakınız: Sevil Gözübüyük, Osmanlı İmparatorluğunda Cizvit Tarikatının Yayılmasında Fransız
}

Kara, A., \& Çavdaroğlu, M., (2021). 20. Yüzyılda Osmanlı Toprakları Üzerinde Kurulan Nişantaşı İngiliz Erkek Mektebi Üzerine Bir Değerlendirme, Asia Minor Studies, Cilt 9 Sayı 2, 814-827, Gönderim tarihi: 14-06-2021, Kabul tarihi: 25-07-2021.

Araştırma Makalesi. 
yerleșerek burada St. Benoit okulunu açmıșlardır. Bu okul imparatorlukta misyonerlerin açtığ1 "ilk" okul olarak kayıtlara geçmiştir. Osmanlının Avrupalılara tanıdığı bu ayrıcalıklar zamanla Fransa dışında diğer ülkelere de tanınmaya başlamıştır. (Topçu, 2007, s. 110/ Kolutek, 2011, s. 3)

Yabancılar Osmanlı devletinden elde ettikleri ayrıcalıkların yanı sıra Islahat Fermanı ile birlikte Osmanlı topraklarında yeni okullar açma girişiminde bulunarak emlak satın alma hakkına kavuştular. $\mathrm{Bu}$ gelişme ile birlikte yabancılar okul açmak için girişimlerde bulunmaya başlamışlardır. Bu doğrultuda Osmanlı tarafından yapılan ilk resmi düzenleme 1869 tarihli Maarifi Umumi Nizamnamesidir. Bu belgenin ilk maddesinde bu okulların özel okul hüviyetinde kurulacaklarını ve bunların yönetimlerinin kişi veya cemaatlere bırakılmasını öngörüyordu. (BOA A.MKT. MHM 700/12, s. 11)

Osmanlı devletinde diğer yabancı devletler gibi okul açan devletlerden biri de İngiltere olmuştur. İngiliz -Osmanlı ilişkileri, 16. Yüzyılda İngiliz ticaret gemilerinin Osmanlı limanlarına gelmesiyle başlamıştır. Osmanlı- İngiliz kültürel ilişkileri ise 1804 yılında bir İngiliz Protestan Kurumu olan “Bible Society” nin kurulması ile başlamıştır. (Esenkal, 2007, s. 138 ve Kocabaşoğlu, 1988, s. 16) Bu durum Osmanlı İngiliz ilişkilerinin gelişmesinde misyoner kurumlarının etkili olduğunu göstermiştir. Osmanlı devletinde bu tür kurumların ve okulların açılmasında İngiliz büyükelçiliği büyük rol oynamıştır. İngiliz Büyükelçiliği himayesinde açılan okulların en eskisi "Ecole Evangelique" dir. Bu okul 1733 yılında İngiliz vatandaşı Rumlar tarafından yapılmış ve İngiliz elçilerinin himayesine verilmiştir. İlk kurulduğunda Osmanlılar tarafindan tanınmayan bu okul 7 Şubat 1895 tarihinde resmen tanınmıştır. (Mutlu, 2005, s. 236 ve Esenkal, 2007, s. 138) İngilizler genel olarak Osmanlı Devleti toprakları içinde Arapça konuşan milletlerin yoğun yaşadığı yerlerde okullar açmışlarsa da bu duruma istisna olarak devletin diğer bölgelerinde de okullar açmışlardır.. Bununla ilgili istatistiklere bakıldığında; Osmanlı topraklarındaki İngiliz misyoner okul sayısı 1856 yılına kadar Kudüs, Yafa, Nablus, İstanbul ve Şam olmak üzere bu vilayetlerde kurulan okul sayıs1 10 iken, 1869 tarihinde bu sayı 30'a ulaşmıştır. (Mutlu, 2005, s. 238) II. Abdülhamid dönemine gelindiğinde Osmanlı topraklarındaki İngiliz okullarının sayısı 95'i bulmuştur. (Esenkal, 2007, s. 139) Bu say1 15 Ocak 1903'te 95 iken daha sonra 115'e kadar çıkmış, (Sevinç, 2009, s. 184 ve Mutlu, 2005, s.240) İngiliz Misyonu Cemiyetinin aynı yıl rakamlarına göre; Kudüs, Nablus, Hayfa, Akka, Gazze, Musul ve Bağdat vilayetlerinde 141 misyoner, 183 yerli destekçi, 1111 İngiliz misyonerin yanı sıra 75 okulda öğrenci sayısı 4600'ü bulmuştur. (Kırşehirlioğlu, 1963, s. 24) Worlds Missions'un 1914 verilerine göre İngiliz Misyon Cemiyetlerinin Osmanlı topraklarında açtığı okulların sayısı 178 olarak tespit edilmiştir. (Sezer, 1999, s. 102)

20. yüzyıla gelindiğinde İstanbul'da 6'sı eğitim alanında olmak üzere toplamda 14 İngiliz kurumu tesis edilmiştir. Bu doğrultuda İstanbul'da ilk İngiliz okulu 1804 yılında İngiliz misyonerler tarafından kurulmakla beraber, İstanbul'daki en erken tarihli İngiliz eğitim kurumu, bir İngiliz misyoner oluşum olan "Free Church Scotland Mission"tarafindan Polonya Musevilerine yönelik olarak 1842 yılında Galata'da açılmıştır. (Ünver, 2018, s. 398) Konumuzu teşkil eden İngiliz Erkek Lisesi, İstanbul'da daimi olarak faaliyet gösteren ilk İngiliz erkek lisesi'dir. Bu okul İngiltere konsolosluğunun himayesinde 1905 senesinde açılmıştır. (Sakaoğlu, 2003, s. 66) Okul ilk olarak Galata Kuledibi'nde bulunan postane binasında daha sonra ise Nişantaşı'nda inşa edilen yeni binasına taşınmıştır. Konu ile ilgili yapılan arşiv taramasında; Okul Beyoğlu'nda Firuz Ağa Mahallesi Beyoğlu Caddesinde yer alıp, okulun yapılması için Osmanlı Hükumeti tarafından İngiltere Sefaretine dönemin

Elçilerinin Rolü, Avrasya Sosyal ve Ekonomi Araştırmaları Dergisi (ASEAD) Eurasian Journal of Researches in Social and Economics (EJRSE), cilt.5 Say1:12, 2018,s.637. 
padişahı tarafından arsanın tapusu verilmiştir. Ancak Galata Kuledibi yerine Nişantaşı'nda Teşvikiye mahallesi İcadiye sokağında 26-28-38 numaralı meskenler ve dört taraftan 3600'metrekare olan bahçeli hane satın alınarak arsanın bir kısmına okul inşa edilmek üzere d İngiliz Sefaretine verilmiştir. Bunlarla birlikte arsada bulunan binanın içi onarılarak küçük tamiratlarla geceli talebe ve öğretmenlere tahsis edilmiştir. Öte yandan inşa edilecek okulun herhangi bir vergi ve yükümlülükten istisna tutularak mukataa-i zemineye bağlandığı ve öylece sefaret namına tapuya kaydedileceği kararlaştırılmıştır. Okulun daha önce İngiliz Büyükelçiliğine tahsis edilen Firuz Ağa Mahallesi'nde bulunan arsada neden yapılmadığına gelindiğinde ise sonradan hediye edilen Teşvikiye Mahallesindeki arsanın sağlık ve temiz hava açısından daha uygun olduğu görülmüş bu nedenle Firuz Ağa'daki arsa satılarak Teşvikiye'deki yer satın alınmıştır. Sonuç olarak Sefaretin Firuz Ağa Mahallesi'nde yer alan arsadaki okul hakkının Osmanlı devletinin izin vermesiyle Teşvikiye Mahallesi'ndeki yere nakil ve devir edilip orada okul yapılması talebi uygun görülmüş, okul inşaatı adına dışarıdan getirtilecek inşaat ve tamir malzemeleri için gümrük vergisinden de muaf tutulmuştur. (BEO 3883/291213/ Tarih: 19 Rebiyülahir 1329-19 Nisan 1911) Okulun kurulmasında İstanbul'daki İngiliz elçiliği müsteşarı F. W. Stronge oldukça etkili olmuştur Okulun yönetim kurulunun başkanlıklarını genellikle İngiliz Elçileri yapmış, eğitim öğretim faaliyetleri ise tayin olunan bir müdür vasitasıyla yürütülmüştür. (Ünver, 2018, s. 399)

\section{Nişantaşı İngiliz Erkek Lisesi’nin Yapısı ve İşleyişi}

İngiliz Erkek Lisesi kurucu heyet tarafından seçilen bir kurul vasıtasıyla idare olunan ve İstanbul'da ikamet eden İngiliz çocuklarıyla diğer milletlerden bulunan çocuklara İngiliz eğitimi vermek amaciyla kurulmuştur. (Zükura Mahsus İngiliz Mektebi,1330-1331, s. 4-5) Okul 1905 yılında İstanbul'da kurulmuştur. Okulun fahri başkanı dönemin İngiltere büyükelçisi Sir Lui'dir. İdare heyeti: İdare heyeti başkanı Mösyö Waugh, idare heyeti ikinci başkanı, İngiliz Ticaret odası Başkanı Adam Block, idare heyeti üyeleri: Arthur Baker, R.Fariyo, A. L. Hayden, Nias, Fahri Veznedar: Alfred C. Silley, Fahri Katip: D. Allend, Nakdi Destekçi ve Kefil: J.W. Whittal, Tedavi Doktoru: Dr. John gibi kişilerden oluşmuştur. Okul Nişantaşı'nda Teşvikiye Caddesinde gayet havadar ve güzel bir mevki 'de yer almakta olup öğrencinin hava almasına mahsus geniş ve gayet güzel düzenlenmiş bir bahçeye sahipti. Okulun gündüzlü ve geceli kısımları ayrı binalarda olup, geceli kısmı 45 öğrenciyi rahatlıkla alabilecek 22 odalı İngiliz usulü lavabo, banyo mahalleri ve 1sıtma araçlarına sahipti. Yanında bulunan asıl okul binasında büyük toplantı salonu, jimnastik salonu, resim atölyesi, bir kütüphane ve dokuz sınıf teşkil edilmiştir. (Zükura Mahsus Ingiliz Mektebi,1330-1331, s. 3) Dönemin en önemli İngiliz kurumlarından biri olarak kabul edilen okul, öğrencide sorumluluk bilinci uyandırmaya gayret ederek onların sağlam karakterlere sahip olmalarına çaba gösterme gayesi taşımıştır. Bir İngiliz okulunda okutulması gereken genel derslerden başka Türkçe ve Fransızcanın da okutulmasına önem verilmiştir. Bahsi geçen dönemde okul teşkilatı Osmanlıdaki diğer okullara göre başarılı sonuçları elde etmiş, 1913 yılında Londra ticaret odasından toplamda 88 tasdikname almış olması okulun başarılı çalışmalar yaptığını göstermektedir. (Zükura Mahsus Ingiliz Mektebi,1330-1331, s. 6)

İstanbul İngiliz Erkek Lisesi eğitim kurulu seçkin İngiliz üniversitelerinden gelen öğretmenlerden oluşturulmuştur. Okul müdürü Oxford Üniversitesine mensup Mösyö Saki sırasıyla İngilizce ve Matematik Öğretmenleri, Durham Üniversitesine mensup Mösyö Mayor, Londra Üniversitesine mensup Mösyö H. Alross, J.M. Atkinson, J. A. Alvel, B.A. Layek. Türkçe öğretmenleri Refik ve Ruşen Beylerdir. Fransızca Öğretmenleri, Mösyö Lambert ve Mösyö Ferbiyan'dır. Okulun gece sorumlu Müdiresi Miss Y. T. Graham’dır. Bu kurul ileride gerek duyulması halinde 1914-1915 eğitim y1lı için bir İngiliz öğretmen almaya karar vermiştir. (Zükura Mahsus İngiliz Mektebi,1330-1331, s. 5) Okulun öğretmen kadrosunun 
genellikle İngiltere'nin saygın üniversitelerinden gelen hocalarından oluşuyor olması dikkat çekicidir.

İngiliz Erkek Lisesinde kayıt usulü şu şekildedir: Müdüriyet tarafindan verilen kabul belgesi kayıt olacak öğrencinin velisi tarafından doldurulur. İdare encümeni bazı durumlarda herhangi bir öğrenciyi kabul etmeme hakkına sahiptir. Okula yedi yaşından itibaren öğrenci kabul edilir. 18'ine ulaşıp okumaya devam etmek arzusunda bulunan öğrencilerin velileri okul müdüründen ayrıca izin almak zorundadırlar. 14 yaşında olup İngilizce konuşamayan çocuklar okula ancak encümen idaresinin özel tavsiyesiyle kabul edilebilirler. (Zükura Mahsus Ingiliz Mektebi,1330-1331, s. 6)

Okulda eğitim süresi yıl içerisinde üç kısma ayrılmıştır.

1. Miladi 16 Eylülden başlayıp 25 Aralık'a kadarki dönem

2. Miladi 1 Ocak'tan 31 Mart'a kadarki dönem

3. Miladi 1 Nisan'dan 30 Haziran'a kadarki dönem

Okul tatilleri sene başı ve paskalya tatilleri olmak üzere toplamda 10 gün olarak belirlenmiştir. Yaz tatili Miladi 1 Temmuz'dan 15 Eylül'e kadar devam etmekte olup pazar günleri tatildir. Cumartesi günleri ise bazı fazla dersler ve öğrencinin katılımı lazım gelen oyunlar yapılması için sosyal aktivitelere ayrılmıştır.

Devamsızlık konusu üzerinde titizlikle durulmuş ve okula devam mecburi olarak belirlenmiştir. Buna göre okul Müdürü’nün izni olmadan öğrenci devamsızlık gösteremezdi. Öğrenciden biri okula geç geldiğinde akraba veya velisinden mazereti yazılmış bir belge getirmek zorundaydı. Belli bir nedene bağlı olarak okula gönderilmeyen öğrencinin velisi durumu hemen okula bildirmek zorundaydı. Öğrenciden biri sağlık problemlerinden dolayı okula devam etmediği takdirde okula dönüşünde doktordan bir rapor getirecek ve bu öğrencinin tekrar kabul olunup olunmayacağı okul yönetim kurulu tarafından araştırılıp karar verilirdi.(Zükura Mahsus İngiliz Mektebi,1330-1331, s. 7-8)

İngiliz Erkek Lisesi ders saatlerine baktığımızda; sabahları saat 9'dan 12'yi çeyrek geçeye kadar, öğleden sonra 13.30'dan 16'ya kadar olarak belirlenmiştir. Büyük sınıf öğrencisi için bu saatler artırılabilir. Öğrenci sabahları alafranga saatte ${ }^{2}$ 08:55 ve öğleden sonra 1:25'te okulda bulunmaya mecburdurlar. Okul saat 08:40'ta açılır ve bu saatten önce öğrenci okula giremezdi. (Zükura Mahsus İngiliz Mektebi,1330-1331, s. 27)

Okul yönetiminin üzerinde önemle durduğu bir diğer husus yeni kayıt olan öğrencilerden sağlik raporu talep edilmesiydi. Buna göre yaz tatilinden sonra gerek eski öğrenci ve gerek okula kayıt olmak isteyen çocuklar sağlık durumlarına dair okul tarafından verilen bir raporu akraba veya velilerine imzalatmaları gerekiyordu. Öğrenciden biri bir bulaşıc1 hastalığa yakalandığı takdirde derhal okul müdürüne haber verilir ve bu öğrenci ancak okul müdürünün izniyle yeniden okula gelebilirdi. Okula yeni gelen bir öğrenci bir aş1 belgesi göstermek zorundayd1. (Zükura Mahsus Ingiliz Mektebi,1330-1331, s. 8-9)

Okulu bırakacak öğrenciler için uygulama şu şekilde yürütülmüştür: Çocuklarını okuldan almak isteyen veliler bu durumdan okul yönetimini taksit sonunun bir ay öncesinden haberdar etmeliydiler. Aksi halde gecikmiş taksiti tamamen ödemeleri gerekiyordu. Okulun tahsil süresini tamamlamadan önce derslerinde başarılı olan öğrencinin okuldan alınmasının doğuracağı problemler hakkında çocukların velileri bilgilendirilir. Tahsil ve bilgi kazanma açısından okulun son seneleri daha önce yapılan eğitim öğretimin tamamlayıcısı olduğu, aslında müdürlüğün okulda eğitim gören tüm öğrencileri iyi bir şekilde eğitimlerini

\footnotetext{
${ }^{2}$ Alafranga saat günü 24 saat sayarak, günün başlayışını gece yarısı 01:00 olarak kabul eden saat sistemidir. Ayrıntılı bilgi için bakınız: https://alafranga-saat.nedir.org/ Erişim Tarihi 10.04.2019.
} 
tamamlayarak mezun olmaları gerektiği velilere söylenip çocukların okulda kalmaları için çaba gösterilirdi. (Zükura Mahsus Ingiliz Mektebi,1330-1331, s. 9)

Okul kuralları içinde ödevler ve öğrencinin evde yapması gereken aktiviteler de yer almıştır. Buna göre öğrenci verilen ödevleri evde yapmaya mecburdur. Ödevlerin yapılması için süre öğrencinin yaşına göre bir ile iki saat arası olarak belirlenmiştir. Bu ödev süresinin tam dikkat ve özen ile geçirilmesine dikkat edilmesi ve ödevlerin hazırlanması için öğrencinin geçerli olan süreden daha fazla veya daha az kullandığının müdüriyete haber verilmesi ebeveyn ve velilerinden rica olunur. (Zükura Mahsus Ingiliz Mektebi,1330-1331, s. 9-10)

Eğitim-Öğretim kurulunun kontrolü altında öğrenciler için oyunlar düzenlenmiş ve bütün öğrencilerin ruhsal ve bedensel gelişimleri için tamamının katılması gerekiyordu. Yalnız doktorların sağlık açısından oyun oynamaları riskli olan öğrencilere oyun oynama konusunda muaf tutulmuşlardır. Sporları teşvik etmek ve öğrenciyi bunlara özendirmek için öğrenciler kısımlara bölünmüştür. Top oyunları, jimnastik, yüzme gibi oyunlarda bölümler arasında müsabakalar düzenlenmiştir. (Zükura Mahsus İngiliz Mektebi,1330-1331, s. 10)

Okul yönetimi öğrenci yakınları ve velilerin ziyaretleri için belirli günler ve saatler belirlemiştir. Buna göre okul müdürü öğrenci akraba veya velilerini, taksit zamanında, Salı ve Perşembe günleri saat 13.30'dan 15:00'a kadar ve Cuma günü sabahtan öğleye kadar kabul etmiştir. (Zükura Mahsus Ingiliz Mektebi,1330-1331, s. 10) Okul yönetimi öğrencilerden Kış mevsiminde okulun markasını içeren kasket ile fanila giyilmesini istemiştir. Yaz mevsiminde ise öğrenci yine okulun markasını içeren hasır şapka giyer, arzu edenler fes de giyebilirlerdi. Futbol ve Kriket oyunlarını oynamak için öğrencide özel kıyafetler giyilmesi zorunluluğu vardı. Öğrencilerde okulun kendi üniforması yok ise öğrencinin koyu renk elbise giymeleri okul tarafindan ihtar edilmiştir. (Zükura Mahsus Ingiliz Mektebi,1330-1331, s. 11)

İngiliz Erkek lisesinde öğle yemeği, okulda tedris heyeti ile beraber yemek isteyen her öğrenci ayda 8 kuruş verir, bazen okulda yemek yemek isteyen her defa için beş kuruş ve yemeğini yanında getirenlerin ise 20 kuruş sofra ücreti vermesi gerekiyordu. (Zükura Mahsus İniliz Mektebi, 1330-1331, s. 25-26)

Okulun öğrencilerin istifade etmeleri için bir kütüphanesi vardı. Öğrenciler arzu ettiği kitapları okuma hakkına sahipti. Son sınıftaki öğrencinin etütlerine ve derslerine katk1 amacıyla kütüphaneyi kullanmaları için kolaylık gösterilmiş ve çalışma ortamı sağlanmıştır. (Zükura Mahsus Ingiliz Mektebi,1330-1331, s. 11) Ayrıca okulda dersler esnasında takip edilecek kitapların okulda mevcut olduğu ve buradan satın alınabileceği de belirtilmiştir

Okulda çamaşır yıkatmak zorunlu değildir. Çamaşırını okulda yıkatmak isteyen öğrencilerin bunun karşıllğında her üç ayda 6 kuruş vermeleri gerekiyordu. Yılbaşı ve paskalya tatillerinde okulda kalmak isteyen öğrenci müdüriyetten izin talep edecek ve günlük bir çeyrek lira vereceği ifade edilmiştir. (Zükura Mahsus İngiliz Mektebi,1330-1331, s. 26)

Öğrencilere o dönemde özel okul koşullarında eğitim verilmiştir. Bu eğitimlerden biri de müzik alanında verilmiş ve öğrenciye üç ayda bir 3 Osmanlı lirası vermek şartıyla piyano dersi almaları sağlanmıştır. Ayrıca müziğe yeteneği olan öğrencileri okul, koro için bir grup oluşturup buraya yönlendirmiştir. Öğrencilere bu çalışmalar kapsamında Ses musikisi dersi de verilmiştir. (Zükura Mahsus İngiliz Mektebi,1330-1331, s. 11) Okulda öğrencilerin doğayı tanımak ve doğada hayatta kalabilme yeteneklerini ve doğaya uyum sağlama meziyetlerini geliştirmek için izcilik dersleri verilmiştir. İngiliz okullarındaki izcilik teşkilatının genel amacı beden ve ahlak terbiyesinin geliştirilmesi olarak belirlenmiştir. Okulda spor oyunları dört şubeye ayrılmıştır. Zikrolunan şubelerin özellik ve işleri okulca tayin edilen subayların idaresine verilmiştir. Her sınıfta öğretmenin idaresi altında bulunan bir takım "çavuş" veya müzakereciler de vardır. Bu kişiler sınıfta ve öğrencinin mesaisine ait hususlardan sorumlu 
tutulmuşlardır. $\mathrm{Bu}$ suretle öğrenci daha küçük yaşta kendisini güzel idareye ve amirlerine karşı itaat ve güvene alıştırılmış oluyordu. Okulun izlemekte olduğu amaç yalnız İngilizce Eğitim-Öğretim ile öğrencinin bilgi kazanmasıyla sınırlı kalmıyor, öğrenciye ileride hayata atıldıkları zaman hayattaki diğer temel bilgileri edinmeleri sağlanıyordu.

Öğrenci son sınıfa geldiğinde okulda almış olduğu eğitimin karşılığı olarak hayata dair çalışmaların ve kazanımların meyvelerini almaya başladığı görülmüştür. Ayrıca sağlığın korunması açısından okulca kabul edilen bazı talimatlar oluşturulmuştur. Bu talimatlarda her şey sırasıyla düşünülmüş, geceli öğrencinin giyeceği elbiseye kadar belirlenmiştir. Yanı sıra okulun adetlerine ve alışkanlıklarına öğrencinin çok kısa sürede uyum sağlaması gerektiği vurgulanmıştır. Uyum sorunu yaşayan öğrenciler için okulda görevli doktorun da tavsiyesiyle ebeveynlerden destek alınabileceği belirtilmiştir. (Zükura Mahsus İngiliz Mektebi,1330-1331, s. 14-15) Geceli öğrencilerin eğitimi, okul ücretleri de aşağıdaki gibi karara bağlanmıştır:

Geceli öğrenci gerek tedris kurulunun gerekse müdirenin gözetimi altında okulun geceli kısmında ikamet ederler. Okul idaresi on beş günde bir her öğrencinin eline kendi gayret ve güzel davranışlarını, sınıflarında ve şubelerinde elde ettikleri dereceleri yazan bir cüzdan verirdi. (Zükura Mahsus Íngiliz Mektebi,1330-1331, s. 27) Buradan anlaş1lacağı üzere karne sisteminden ziyade kısa süreli öğrenci değerlendirmelerini içeren not ve davranışlar ile ilgili çizelgeler verilmiştir. Yaşları 12'den aşağı olan öğrenciler her taksitte 4 Osmanlı lirası, 12 'den yukarı olanlar ise her taksitte 5,5 Osmanlı lirası vermeleri gerekiyordu. Bu ödeme her üç ay başında yani eylül, ocak nisanda peşinen ve tamamen yapılırdı. Ücretler ve diğerleri için aylık ödeme kabul edilmezdi. Her öğrenci kırtasiye gereçleri ve oyunlar için her üç ay taksiti sonunda ek olarak 32 kuruş gümüş akçe verirdi. Kitap ve öğle yemeği hesapları her taksit sonunda kesilip, aynı zamanda okulda öğrenci olan iki kardeşin ödemesinden yüzde on ve kardeş sayısı üç veya daha fazla olanlar için yüzde 15 indirim yapılırdı. (Zükura Mahsus Ingiliz Mektebi,1330-1331, s. 27)

Her hafta başında evine giden geceli öğrenci (yani okulda Pazartesi sabahından Cuma akşamına kadar bulunanlar) her taksitte 15 Osmanlı lirası; ayda bir defa (Cuma öğleden sonra pazartesi sabahına kadar) evine giden öğrenci için her taksitte 12 Osmanlı lirası; "yılbaşı paskalya" tatilleri dâhil olmadığı halde üç ay okulda kalan öğrenci 13 Osmanlı lirası vermekle mükelleftir. Ayda bir defa evine gidenler bulunulan miladi ayın son Cuma günü olsa da bu Cuma ayın beşinci cuması olsun- evlerine dönerlerdi. (Zükura Mahsus Ingiliz Mektebi,13301331, s. 27)

\section{Okutulan Dersler ve İçerikleri}

İngilizler diğer ülkelerde uygulanan eğitim-öğretim usul ve uygulamalrından birçok yönden farklı bir metot uygulamışlardır. Öğrencinin okuldaki dersleri dışında kendileri için yararlı olan hayat ile ilgili dersler almalarını sağlamış, hayatta başarılı olabilmek için yalnız okulda verilen eğitimin yeterli olmayacağını düşünmüşler ve bu esaslar üzerine hareket etmişlerdir. Öğrencilere sorumluluk alabilme, beden sağlığı ve temizlik, üstlerine itaat etme gibi kazanımların yanı sıra kişisel gelişsim gibi erdemler kazandırılmıştır. Vücut sağlığı ve diğer konularda da bilgili olabilmeleri için öğrenciye sınıfta; koruma, görevde sorumluluk, liderlik, kendisini güzelce idare etme zihin terbiyesi aşılanması amaçlanmıştır. Ayrıca insanlar arasında ve büyük meclislerde bulunulduğunda tavır ve hareketlerde, güzel yazma-konuşma sanatında ve diğer meziyetlerin kazanılmasında öğrencinin gelişme kazanabilmesi için çalışmalar yapılmıştır. Öğrenciler okul eğitmenlerinin denetimi altında kendi işlerinin büyük çoğunluğunu kendileri idare eder ve çekip çevirir hale gelene kadar bu uygulama devem etmiştir. (Zükura Mahsus Ingiliz Mektebi,1330-1331, s. 12-13)

İngiliz Erkek Lisesinde öğrenciler iki esas üzerine sınıflandırılmıştır: ilk olarak sınıf ikinci olarak ise şube usulü uygulanmıştır. Ayrıca okutulan derslere göre ise Tali ve Ali olarak 
isimlendirilmişlerdir. Buna göre ayrılan sınıflarda İngilizce ve diğer diller, tarih ve coğrafya gibi dersler verilmesi kararlaştırılırken, şubelerde ticari dersler ile matematik, fen, resim ve ticari konuları okutma hususu üzerinde durulmuştur. Eğer öğrenci fen şubelerinin birinde başarısız olursa bu durum diğer şubelerde ilerlemesine engel teşkil etmeyecek ve rahatça eğitimine devam edecektir.(Zükura Mahsus Ingiliz Mektebi,1330-1331, s. 25) Bahsi geçen sınıf ve şubelerin ve okutulacak derslerin tablosu aşă̆ıda verilmiştir.

Tablo 1: İngiliz Erkek Lisesi ders programı tablosu

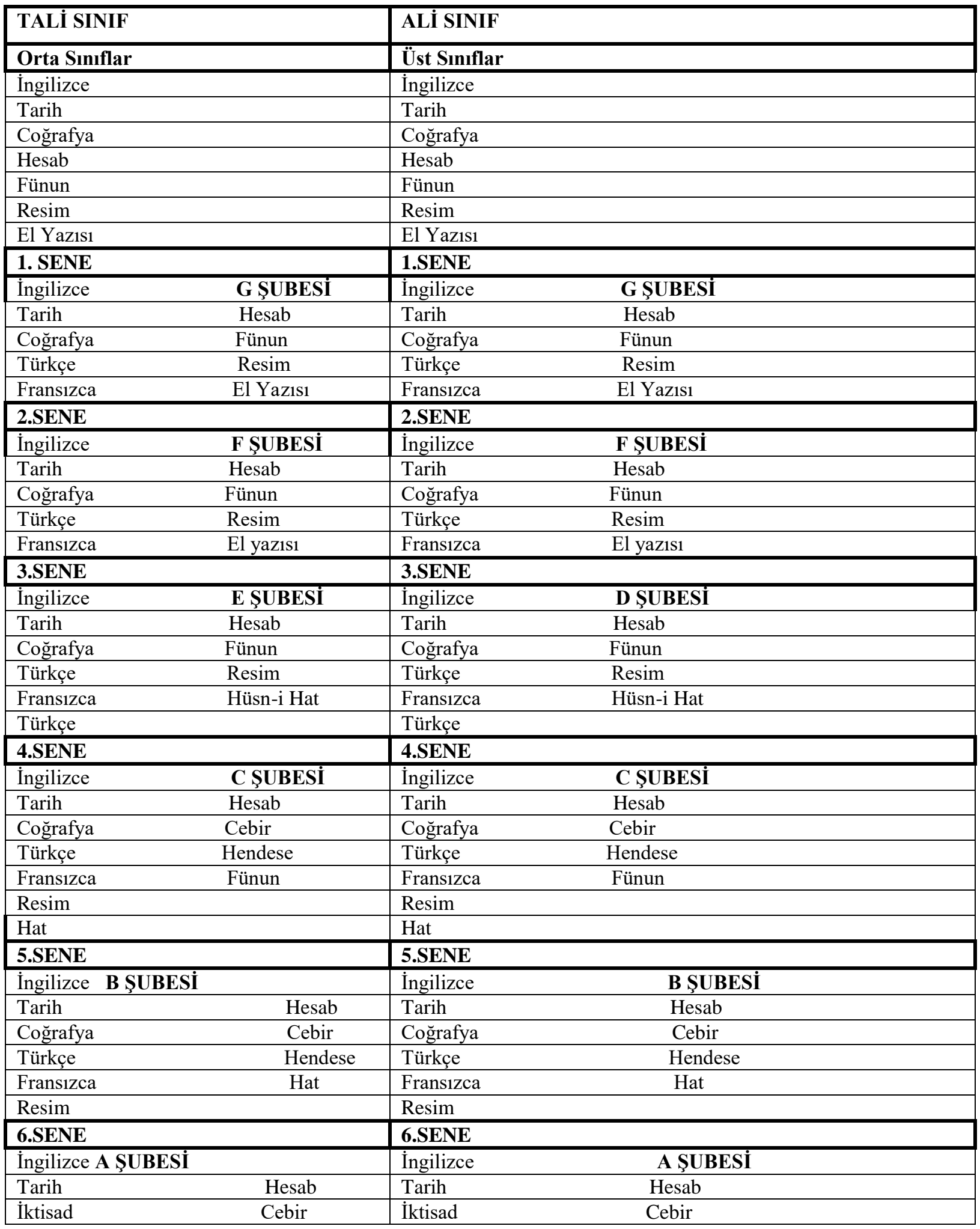




\begin{tabular}{|ll|lc|}
\hline Coğrafya & Hendese & Coğrafya & Hendese \\
\hline Türkçe & Hat & Türkçe & Hat \\
\hline Fransizca & Resim & Fransizca & \\
\hline Muhasebe & & Muhasebe & \\
\hline Steneografi & Steneografi & \\
\hline & & İHTíSAS SINIFI & \\
\cline { 2 - 3 } & Riyaziyat & \\
\hline & Ticaret & \\
\hline & & Stenografi & \\
\hline
\end{tabular}

Tablo 1'de verilen derslerin içeriklerine bakıldığında; Tali ve Ali 1. kısım sınıflarda ilk dersler İngilizce, Tarih ve Coğrafya'dır. Bunlardan İngilizce derslerinde öğrencilere eğitimde Berliç ve Gomen usulleri kullanılarak İngiliz dilinin fiilen ve uygulamalı olarak eğitimi, karşılıklı konuşma, resim ve şekiller üzerinde anlama çalışmaları, fonetik yani dilin seslendirilmesi, okuma, kelime ezberi ve yazma gibi uygulamalar yapılmıştır. Tarih dersinde ilk olarak genel bilgiler ve genel olaylar ile tarihi mevzular arasındaki bağlantılar, tarihi ifadeler, menkıbeler, tarih terimleri tarihte yaşamış büyük kral ve padişahları, yaşanan büyük savaşları, kullanılan silahları, sancakları, posta pulları ve paralar, Türk tarihinden birtakım geleneksel hikâyeleri içermektedir. Son olarak coğrafya dersi ve içeriği hakkında bilgiler verilmiştir. Coğrafya dersinde öğrenciye; Plan ve Haritaları, coğrafya terimlerini ve lüleci çamurundan yapılan kabartmalar vasıtasıyla meydana getirilen resimler ile izah ve beyan gibi uygulamaları, İstanbul ve Türkiye'nin hal ve coğrafyasına ait bazı fikirler ve görüşleri içeren bilgiler verilmiştir. Tali ve Ali 2. kısım sınıflarda öğrencilere Hesap, Fen, Resim, El yazısı gibi dersler verilmiştir. Bahsi geçen derslerin içeriğine baktığımızda; Hesap dersinde öğrencilere sayı sayma, rakamlar, çarpım tablosu ve dört işlem üzerine basit ve genel egzersizler yapılmıştır. Fen dersinde, Tabiat araştırmaları, görüş ve izahat, bitkiler ve hayvanlar ile ilgili genel bilgiler verilmiştir. Resim dersinde, Basit el ile yapılabilen resimler ve ölçüm gibi genel bilgiler öğretilmiştir. El yazısı dersinde ise El yazısı veya güzel yazı harflerinin, sayılarının oluşumu ve yazımı, güzel yazı defteri üzerinde yazı yazma etkinliği, tahtada güzel yazı yazma egzersizleri öğretilmesi kararlaştırılmıştır. Bahsi geçen bu dersler ile eğitime başlamak için öğrencilerin İngilizcelerinin yeterli derece de iyi oluncaya kadar bu sınıfta kalmalarının önemli bir husus olduğu vurgulanmıştır. (Zükura Mahsus İngiliz Mektebi,1330-1331, s. 16)

\section{Birinci Sinıf}

İngiliz Erkek lisesinde ilk kısmı geçen öğrenciler birinci sınıftan derslere başlama hakkı kazanmıştır. Birinci sınıfta okutulan dersler İngilizce, Tarih, Coğrafya, Türkçe ve Fransızcadır. Burada dikkat çeken bir husus Türkçe dersleri sadece Türk öğrenciler için verilmiş olmasıdır. Bu sınıfta okutulan ders içeriklerine baktığımızda; İngilizcenin önceki kısımdan farklı olarak, sözlü, yazılı kolay kanunlar, kompozisyon, seslerin ayırt edilmesi, okuma, yazma, konuşma, dilin ilk kuralları, başlıca fiiller gibi konular üzerinde durulmuş olduğu görülmüştür. Tarih dersinde, İngiliz tarihinden hikâyeler ve tarihte gerçekleşmiş olayların zaman ve tarihini gösteren harita ve cetveller ile ilgili bilgiler yer almıştır. Coğrafya dersinde, İngiltere haritasının fenni olarak incelenmesi, Türkiye haritası, coğrafyanın ilk konularıyla (fiziki coğrafya, dünyanın şekli ve hareketi, mevsimler, enlem boylam, vs.) yerin katmanlarına dair malumat verilmiştir. Fransızca dersine baktığımızda içerik olarak, doğrudan doğruya en kolay bilimsel usul ile dilin okutulması ve konuşma gibi bölümlerden oluştuğu görülmüştür. Bunun yanı sıra okulda mevcut Fransızca öğretimi ve Türkçe sınıfları İngilizce için kabul olunan esastan farklı esaslar üzerine olduklarından bir öğrencinin Fransızca ve İngilizce de farklı sınıflarda bulunabileceği ifade edilmiştir. Birinci sınıfın $G$ şubesinde okutulan dersler ise hesap, resim, el yazısı ve hüsn-ü hat ve fen dersleri'dir. Hesap dersinde, dört işlem, basit işlemler, basit kesirler, zihni hesaplar verilirken, fen dersinde doğadan 
araştırmalar, incelemeler, izahat, beyanatlar, hayvanlar, bitkiler, yer küre üzerine gerçekleşen olaylar ve coğrafya ile bilinen kolay fizyografi kısmı da bu derse dâhildir. (Zükura Mahsus Ingiliz Mektebi,1330-1331, s. 17) Resim dersinde öğrencilere el ile basit resim yapmak, maddeler ve basit eşyaların resmi, ilk resim olarak doğaçlama lüleci çamuru ile model veya başka resim yapmak gibi edinimler kazandırılmaya çalışılmıştır. El yazısı veya Hüsn-ü Hat dersleri ise başlangıç sınıfının aynısıdır. (Zükura Mahsus İngiliz Mektebi,1330-1331, s. 18)

\section{İkinci Sınıf}

İngiliz Lisesi ikinci sınıf dersleri İngilizce, Tarih, Coğrafya, Türkçe, Fransızca olarak belirlenmiştir. İkinci sınıf $\mathrm{F}$ şubesi için belirlenen dersler; Hesap, Fen, resim, el yazısı ve hüsn-ü hat. Ders içerikleri açısından bakıldığında; İngilizce dersinde, kompozisyon yazma ve konuşma, okuma, yazma, ezber dersi, dil kurallarından sonuç çıkarma usulü üzerine kelimelerin dilbilgisi açısından incelenmesi gibi uygulamaların yapılması belirlenmiştir. Tarih dersleri içerik olarak, Büyük Britanya adalarının tarihini, Genel İngiltere tarihini ve Türk öğrenciler için Türkiye tarihi gibi konuları içermiştir. Öğrencilere okutulan diğer derslerden biri coğrafya'dır. Coğrafya dersinin içeriği; yer küre üzerindeki ülkelere dair genel bilgiler, bunların sakinleri ve ahalisi, büyük Britanya adalarının geçerli olan coğrafi durumu, Türkiye'ye dair geniş coğrafi bilgiler olarak belirlenmiştir. Daha önceki sınıflarda olduğu gibi bu sinıfta da Türkçe dersi sadece Türk öğrenciler için verilmiştir. Burada Türkçenin içeriği ile ilgili bilgi verilmeyişi dikkat çekici bir durumdur. Fransızca dersinde doğrudan doğruya uygulama usulü, konuşma, okuma, ezber dersleri, fiillerin karşılaştırılması gibi uygulamalar yer almıştır. İkinci sınıf $\mathrm{F}$ şubesi derslerin içeriğine bakıldığında Hesap dersi, ilk kuralların ve esasların tekrarı, problemler, Osmanlı para usulüne göre ondalık hesaplar, zihni hesaplamalardan oluşmuştur. Fen dersi felsefenin ilk devreleri, yer ilmi, doğa ilmi üzerine yapılan incelemeler üzerine tashih çalışmaları gibi kısımlardan meydana gelmiştir. El Yazısı ve Hüsn-ü Hat dersinde çeşitli yazılar, harflere alışkanlık, güzel yazıyı çoğaltmadaki kabiliyet ve iktidar, eldeki istikrar yani elin titremesi hususu, mektup zarfları üzerine yazmak yani adres yazmak gibi uygulamalar verilmiştir. Resim dersinde ise G şubesiyle aynı olmakla beraber ek olarak üç boyutlu resimler yapma öğretilmiştir. (Zükura Mahsus Íngiliz Mektebi,1330-1331, s. 18-19)

\section{Üçüncü Sınıf}

İngiliz Lisesi üçüncü sınıf derslerinin ilki İngilizcedir. Bu ders içerik olarak kitabet, cümle ve kelimelerin oluşturulması, dilbilgisinin tahlil edilmesi, okuma, ezber, yazma ile kolay yazı yazma ve ibarelerin oluşturulması gibi kısımlardan oluşmuştur. Tarih dersi içeriğine baktığımızda, Genel Avrupa tarihi, Avrupa'nın genişlemesi ve oluşumu, Büyük devlet adamlarının biyografileri, talep edenler için de Tercüme-i Osmani gibi bölümlerden meydana gelmiştir. Coğrafya dersi bu sınıfta biraz daha teferruatlı anlatılmış ve konu açısından genişletilmiştir. Konular, coğrafi kavram ve tabirlerinin tekrarı ile matematik coğrafyası hakkında bazı incelemeler, İngiltere'nin coğrafyası, Avrupa kıtasında şehirler ve siyasi-idari bölgeler, Balkan Yarımadası, Akdeniz ve Karadeniz havzaları hakkında hususi araştırmalar ve incelemeler olarak belirlenmiştir. Dil derslerinden olan Fransızca dersinin konuları, şekil bilgisi, birinci basamak okuma-yazmaya dair izahlar, ezber, konuşmadan ibarettir. Türkçe dersi ise daha öncede ifade edildiği gibi sadece Türk öğrencilere verilmiştir. (Zükura Mahsus İngiliz Mektebi,1330-1331, s. 19)

Üçüncü sınıf E şubesi öğrencilerinin sorumlu olduğu derslerine baktığımızda sırasıyla ders ismi ve içerikleri şu şekildedir: Hesap dersi, Tekrar, Çarpma ve Bölme, Obeb-Okek, alan ölçüleri, oran-orantı, basit faiz hesaplama, İngiliz, Türk ve Fransız Parası ile karşılaştırmalı zihni hesaplar, ondalık sisteme göre yapılmış metre usulü gibi konulardan sorumlu oldukları ifade edilmiştir. Resim dersinin F şubesi ile içerik-konu olarak aynı olduğu belirtilmiştir. Fen 
dersi, genel tekrar, ilm-i hayvanat üzerine daha geniş araştırma-inceleme, hayvanlarda azaların görevleri, bitkiler ve bitkilerde azaların görevleri, yer bilimi gibi kısımlardan meydana gelmiştir. Program içindeki bir diğer ders Geometri' dir. Geometri dersinde, tarifler, çizgiler, açı ve trigonometri üzerine alıştırmalar, en basit alıştırmaların sağlaması gibi konular yer almıştır. Güzel Yazı dersinde, önceki uygulamaların aynı olup matbu yazı taklit etmek ve çizgisiz kâğıda yazma talimi yapılmıştır. (Zükura Mahsus Ingiliz Mektebi,1330-1331, s. 1920)

Okulun ders programı içinde bulunan Türkçe dersleri ile ilgili izlenen yol şu şekilde verilmiştir: İlk üç sınıfın Müslüman öğrencisi üç özel sınıfta Türkçe tahsil ederler. Bu saatler okulun akışı dışında olursa Türkçe öğrenmek isteyen diğer çocuklar bu sınıfları takip ederler. Bahsi geçen bu üç sınıfın programı şu şekildedir:

Birinci Sınıf: Öğrenci elifba, hat, ilk okuma ve düzyazı gibi konulardan sorumludur.

İkinci Sınıf: Hat ve Okuma, Yazma (Biraz daha güç), dilbilgisi kuralları, kolay şiirden ezber gibi konulardan sorumludur.

Üçüncü Sınıf: Okuma, yazma, şekil bilgisi, ezber, kitabet vazifeleri, bazı tarihi ve edebi metinlerden sorumlu tutulmuşlardır. Dördüncü sınıftan itibaren Türkçe dili öğrenmek isteyen çocuklara düzgün ve zamanlı bir şekilde öğretilir. Âli sınıflarda çocuklar Türkçe yerine Latince veya özel İngilizce veya Matematik ve "daktilografi" derslerini takip edebilecekleri ifade edilmiştir. (Zükura Mahsus İngiliz Mektebi,1330-1331, s. 20)

Üçüncü Sınıf Âli Kısım D Şubesi, üçüncü sınıfa (tâlî şubeye) denktir ve dersleri hemen hemen aynıdır. Bu sınıf okula erken yaşta dâhil olup âli sınıf derslerini takip edebilecek düzeyde İngiliz diline vakıf olmayan ve küçük sınıflara yaşlarından dolayı dâhil olmayan çocuklar içindir. İlk sınıfları başarıyla bitiren çocuklar çoğunlukla bu sınıfta okumaya mecbur değildirler. Bu iki sınıf arasındaki başlıca fark: konuşma, matematik, konuşma usulüne dair olan sonradan incelemeler, görüşlerden ibarettir. (Zükura Mahsus Ingiliz Mektebi,1330-1331, s. 21)

\section{Dördüncü Sınıf}

Okulun dördüncü sınıf dersleri konu olarak önceki sınıflara göre biraz daha ağırlaştırılmıştır. Bu sınıfta İngilizce dersinin konuları edebiyat, yazı yazma usulü (mektup, dilekçe vs.,) haberleşme usulü, dilbilgisi, yazının yorumlanması gibi kısımlardan oluşmuştur. Tarih dersinde sadece İngiltere, İngiliz İmparatorluğu tarihinden bilgiler verilmiştir. Coğrafya dersinde, İngiltere İmparatorluğu, Avrupa'nın ve Dünyanın ticaret ile ünlü olan șehirlerinin coğrafyası gibi konuların öğretilmesi belirlenmiştir. Türkçe dersi, Berliç Usulü, Elifba, Okuma, basit yazılar ile dilbilgisi kurallarına örnekler gibi kısımlardan, Fransızca dersi basit dil bilgisi kuralları, fiillerin karşılaştırılması, yazma, okuma, ezber, kitabet(resmi yazı yazımı) gibi bölümlerden meydana gelmiştir.(Zükura Mahsus Ingiliz Mektebi,1330-1331, s. 21) Dördüncü sınıf $\mathrm{C}$ şubesi derslerine bakıldığında bu kısımda da gerek ders gerek konu içerikleri bakımından biraz daha ileri konular olduğu görülmektedir. Hesap dersi, paralar, ağırlık-ölçüler, sadeleştirme, obeb-okek, çarpma işlemi, sayılar ve boş küme, ondalık kesirler, orant1, basit kesir, basit yüzde faizi, kar-zarar, dikdörtgenin yüzeyi gibi konulardan oluşmuştur. Cebir dersi, ornatma, basit denklem, birleşik denklem ve çarpan-çarpım gibi konulardan oluşmuştur. Geometri dersi; tekrar, ispat, açı, trigonometri, paralel teoremler ile sağlama problemleri, Fen dersi, yerçekimi ve sıcaklık, 1 şık, ses, manyetizma ve elektrik konuları, resim dersi, balçık resimlerinin taklidi, doğal resim, genel eşya, zihni resim ve son olarak Hat derslerinde emirname, bordro, basımcılık fenni, usul-i defteri yani defter-i kebir (muhasebe kaydı tutma usulü) üzerine basit egzersizler ve vezne defteri gibi konular verilmiştir. (Zükura Mahsus Ingiliz Mektebi,1330-1331, s. 21-22) 


\section{Beşinci Sınıf}

Okulun dördüncü sınıf dersleri konu ve içerik olarak normal sınıflarda beş ders okutulmuş B şubesinde beş ders olmak üzere toplamda on ders okutulmuştur. Normal sınıfta verilen derslerden ilki İngilizcedir. İngilizce dersinde öğrencilere resmi yazı yazma, tahlil, dil tarihi, etimoloji, dil bilimi hakkında ilk incelemeler araştırmalar, iş İngilizcesi ve yazı gibi konuları öğretilmiştir. Tarih dersinde ticaret tarihi ve ilkçağ tarihi, Coğrafya dersinde tabii coğrafya, Türkçe dersinde Berliç usulü sonrası küçük imlalar, dilbilgisi, okuma, kolay kelimeler, (arabi, farsi kolay ezber) son olarak ise Fransızca dersinde kuralların tekrarı, okuma tahlilleri, resmi yazı yazma, ticari mektuplar gibi konular işlenmiştir. (Zükura Mahsus Ingiliz Mektebi,1330-1331, s. 22) Beşinci sınıf B şubesi derslerine bakıldığında Hesap dersinde, yüzeyler, hacim, yüzde faizi, basit ve bileşik faizler, sermaye, tahvilat, olasılık, logaritma, muhasebe, zihni çabuk hesap yapma usulü, cebir dersinde, tekrar çarpan ve çarpım, ornatma, basit kesir, ikinci derece bilinmeyenli denklem, Geometri dersinde, düzlemsel şekiller, Hat dersinde Makbuz, senet ve diğer ticari evrakın müsveddesini yapma ve kabartma yazma son olarak Resim dersinde ise balçık resimlerinin taklidi (daha gelişmişi) gibi konuların öğretileceği belirlenmiştir. Çeşitli sebeplerden dolayı okulu bırakmak zorunda kalan öğrenciler için eğer okulu üçüncü sınıfta bırakmışsa bir sınav yapıldıktan sonra bahsi geçen bu öğrencilerin müessesenin ikinci derecede bir tasdiknamesi derecesinde olan diplomasını alabilecekleri ifade edilmiştir. (Zükura Mahsus İngiliz Mektebi,1330-1331, s. 23)

\section{Altıncı Sinif}

Okulun altıncı sınıfındaki öğrenciler on iki dersten sorumlu tutulmuşlardır. Bahsi geçen derslerin içeriklerine baktığımızda; İngilizce dersi, resmi yazı yazma, yazma usulü, edebiyat, ünlü yazarlar hakkında araştırma, inceleme, cümlecik oluşturma, Tarih dersi, genel bilgiler, ticari ve iktisadi tarih ve Meşrutiyet tarihi, İktisat dersi, teoriler, mevcut toplumun hal ve şartlarına göre iktisadi modeller ve maliye hakkında uygulamalar, Coğrafya dersi, genel coğrafya hakkında genel araştırma, inceleme, hususi mevzuat, ulaştırma, göç, coğrafi şartların tarihe olan etkisi, Türkçe dersi, genel tekrar, şekil bilgisi, yazı yazma, ezber, resmi yazı yazma, mektup, tarih ve edebiyattan seçilmiş, Arapça kelimeler, Türkçe ileri düzeyde ticari mektuplar ve dilbilgisi kuralları, Fransızca dersinde ise Kitabet, cümle bilgisi, edebiyat, meşhur yazarlar hakkında araştırma, ticari mektuplar ve tercüme gibi konular öğretilmiştir. $\mathrm{Bu}$ sınıfın mesleki dersler kısmı altı dersten oluşmuştur. İçeriklerine baktığımızda, Hesap dersinde ticari hesap, poliçe, ondalık kesirler, logaritma hesabı, orantı geometrisi, kile hububat ölçüleri, Cebir dersinde ikinci derece denklemler, koordinat sistemi, niceliksel orantısızlık, Geometride tekrar, oran-orant1, Hat dersinde, hızlı yazı yazma, Resim dersinde, resim geometrisi, düzlem geometrisi, uzay geometrisi, zihinden yapılacak güç resimler son olarak Muhasebe ve Usul-ü Defteri derslerinde ise her türlü ticarette kullanilan hususi defterler, ticari hukuk vs. Stenografi Usulü ve hızlı yazma gibi konuların öğretileceği vurgulanmıştır. (Zükura Mahsus Íngiliz Mektebi,1330-1331, s. 23-24) Buradaki dersleri verdikten sonra öğrenci mezun olmaya hak kazanır. Ayrıca okulun mevzuatı ile ilgili bu metinde tam tasdiknameyi almak için "en az dört sene mektebin eğitim-öğretimini takip etmiş ve sınavlarını kazanmış olmalıdırlar" ibaresi yer almıştır. (Zükura Mahsus Ingiliz Mektebi,1330-1331, s. 24)

\section{Uzmanlık Sınıfı ve Eğitimin Sona Ermesi}

$\mathrm{Bu}$ sınıf bir sene ek tahsil görmek isteyen öğrenciler için oluşturulmuştur. Yabancı diller, Matematik ve ticarette uzman olarak almak istedikleri tasdiknameleri edinebilirler veya hususi araştırmalar yaparak kendilerini geliştirebilmeleri için tesis edilmiş bir sınıftır. Buradaki dersler ve içerikleri şu şekildedir: Matematik: trigonometri, hendese-i aliye ve mühendis mekteplerine dâhil olmak için lazım gelen diğer maddeleri içerir. Ticaret: Usul-i 
defteri, stenografi hakkında geniş inceleme araştırma (geniş tetebbuat), Stenografi dersi, iktisat, iktisat tarihi, banka mali ilmi, simsarlık, yürürlükte olan kanunların tatbikatı gibi konuları içermiştir. (Zükura Mahsus İngiliz Mektebi,1330-1331, s. 24-25)

Osmanlı Devleti'nde XVIII. yüzyılın ikinci yarısında, özellikle Mühendishane-i Bahrii Hümayun'un açılmasıyla eğitimde modernleşme hareketleri başlamış olup eğitim programları (müfredat) da bu minvalde oluşturulmaya çalışılmıştır. Gerek devlet gerekse azınlık ve yabancı okullarında okutulan dersler ve içeriklerinin çoğunlukla aynı olduğu görülmektedir. $\mathrm{Bu}$ derslerin içeriklerinin ise öğrencilerin çeşitli becerilerini geliştirmeye yönelik olarak geliştirildiği, ezberci bir eğitim sisteminin dışına çıkılmaya çalışıldığ söylenebilir ${ }^{3}$.

\section{Sonuç}

Osmanlı'da yabancı okulların açılması Osmanlı'nın Avrupa devletleriyle kurduğu siyasi ve ekonomik ilişkilerin sonucunda gerçekleşmiştir. Osmanlı'nın ticari ilişkilerinin yoğun olduğu devletlerden biri olan İngiltere ile ticari ilişkiler 16. Yüzyılda başlamış, kültürel alandaki ilişkileri ise 19. Yüzyılın ilk çeyreğinde gerçekleşmiştir. Kültürel anlamdaki ilişkilerin başlamasıyla Osmanlı topraklarında İngiliz okulları açılmaya başlamıştır. Türk topraklarında çeşitli dönemlerde "Yabancı Okullar" olarak adlandırılan okullar açılmıştır. Bu okullar bağlı bulundukları devletlere göre isimlendirilmiş ve bu devletlerin misyonlarına hizmet etmişlerdir. Osmanlı topraklarında açılan yabancı okullar genellikle misyonerlik faaliyetleri ile ön plana çıkmışlardır. Bahsi geçen yabancı okullar Osmanlı devletinin son zamanlarında Osmanlı gayr-i Müslim tebaası tarafından açılan azınlık okullarıyla ortak bir program izlemişlerdir. İngilizler de aynı amaçlara hizmet etmek amacıyla Osmanlı topraklarında okullar açmışlardır.

Osmanlı topraklarındaki İngiliz okullarının açıldığı yerlerden biri de İstanbul olmuştur. 1905 yılında İstanbul'da açılan Nişantaşı İngiliz Erkek Lisesinin eğitim süresi altı yıldır. Eğitimini tamamlayan öğrenciler altı yılın sonunda istekleri doğrultusunda ihtisas yani uzmanlık sınıfına dâhil olabiliyorlardı. Bu durum o dönemde bu okulda verilen eğitimin öğrencilerin yeteneklerini ön plana çıkaran ve bu doğrultuda uzmanlaşmalarını sağlamıştır. Özellikle dil konusunda hassas hareket edilmiş, öğrenciler iyi düzeyde İngilizce öğrenmeden üst sınıflara geçemiyordu. Öğrencilere verilen derslere baktığımızda bilhassa tarih derslerinde İngiliz tarihi ve önemli şahsiyetleri, önemli olayları üzerinde durulması ve Türkçe dersinin sadece Türk öğrencilere veriliyor olması dikkat çekicidir. Dikkat çeken bir diğer husus ise İngilizce dilini ileri düzey bilme şartını Türk öğrencilere de uygulanıyor olmasıdır. Eğitimin kısımlara ayrılması neticesinde meslek derslerine ilgisi olan öğrencilerin meslek kısmına normal derslere ilgisi olan öğrencilerin bahsi geçen kısma yönlendirilmeleri öğrenciler açısından önemlidir. Nişantaşı İngiliz Erkek Lisesi eğitim kadrosuna baktığımızda genellikle İngiltere'nin sayılı üniversitelerinden gelen hocaların burada görevlendirilmesi ve İngiltere'nin İstanbul konsolosunun bu okula önem vermesi üzerinde durulması gereken bir diğer husustur. Son olarak burada diploma almaya hak kazanan öğrenciler ihtisas sınıflarında ticaret ve diller üzerine uzmanlaşma imkânı bulmuşlardır.

\footnotetext{
${ }^{3}$ Osmanlı'da modern anlamda eğitim veren ve Milli Mücadele'nin kazanılmasında oldukça önem arz eden birçok komutanın mezun olduğu askeri rüştiyelerde verilen dersler ve eğitim programları bu duruma örnek gösterilebilir. Öğrencilerin çeşitli becerilerinin kazandırılmasına yönelik olarak yapılan eğitim programlarının Bloom Taksonomisi'ne göre değerlendirildiğinde ortaya çıkan sonuç için bkz. PATOĞLU, Emrah Berkant, Osmanlı Devleti’nde Askeri Rüştiyeler, Yayımlanmamış Doktora Tezi, Gaziantep Üniversitesi, Sosyal Bilimler Enstitüsü, Gaziantep, 2018.
} 


\section{Arşiv kaynakları}

\section{Kaynakça}

Zükura Mahsus İngiliz Mektebi, 1330-1331, İstanbul: Dersaadet: Fratelli Hayim Matbaas1. BEO 3883/291213/ Tarih: 19 Rebiyülahir 1329-19 Nisan 1911.

BOA, A.MKT. MHM 700/12, sayfa.11.

\section{Tetkik eserler}

Esenkal, E., (2007). Yabancı ülkeler tarafindan Osmanlı coğrafyasında açılan okullar, Trakya Üniversitesi Sosyal Bilimler Enstitüsü Tarih Anabilim Dalı, Yüksek Lisans Tezi, Edirne.

Gözübüyük, S., (2018). Osmanlı İmparatorluğunda Cizvit Tarikatının yayılmasında Fransız elçilerinin rolü, Avrasya Sosyal ve Ekonomi Araştırmaları Dergisi (ASEAD) Eurasian Journal of Researches in Social and Economics (EJRSE), 5/12, s. 637.

İhsanoğlu, E., (1999). “Osmanlı eğitim ve bilim kurumları”, Osmanlı Medeniyeti Tarihi, Cilt1, İstanbul: Feza Yay.

Kırşehirlioğlu, E. G., (1963). Türkiye'de misyoner faaliyetleri, İstanbul.

Kocabaşoğlu, U., (1988). Osmanlı İmparatorluğu'nda 19. yüzyılda Amerikan matbaaları ve yayımcllı̆̆l, İstanbul.

Kolutek, M., (2011). Fransa'nın Doğu Akdeniz havzasındaki misyonerlik faaliyetleri, Hatay Mustafa Kemal Üniversitesi Sosyal Bilimler Enstitüsü Tarih Anabilim Dalı, Yüksek Lisans Tezi, Hatay.

Mutlu, Ş., (2005). Osmanlı Devleti'nde misyoner okullarl, İstanbul.

Sakaoğlu, A. S., (2003). "High school-İngiliz k1z ve erkek liseleri”, İstanbul Ansiklopedisi, Cilt IV, İstanbul: Tarih Vakfi Yay.

Sevinç, N., (2009). Osmanlı'dan günümüze misyoner faaliyetleri okullar, kiliseler, yardım kuruluşları, 7. Baskı, İstanbul: Bilge Oğuz Yay.

Sezer, A., (1999). Atatürk döneminde yabancı okullar (1923-1938), Ankara.

Topçu, F., (2007). Türk eğitim sisteminin tarihsel gelişimi ile yabancı okullarının bu sistem üzerindeki etkileri, Beykent Üniversitesi Sosyal Bilimler Enstitüsü İşletme Yönetimi Anabilim Dalı Eğitim Yönetimi ve Denetimi Bilim Dalı, Yüksek Lisans Tezi, İstanbul.

Ünver M., (2018). Osmanlı Devletinde'ki İngiliz ticaretinin Almanya karşısında gerilemesi tartışmaları bağlamında İstanbul'da İngiliz Erkek Lisesinin kuruluşu/ (The Foundation of English High School For Boys in İstanbul in The Context Of the Debates Over The British Decline Against Germany in Ottoman Trade), Türkiyat Araştırmaları Enstitüsü Dergisi-Journal of Turkish Researches Institute TAED-61, Ocak-January, Erzurum.

\section{Elektronik kaynaklar}

https://alafranga-saat.nedir.org/ Erişim tarihi 10.04.2019. 


\section{Ekler}

Ek.1: Nişantaşı'nda Teşvikiye mahallesi'nin İcadiye sokaği'ndaki İngiliz mektebi'nin inşası. (Maliye, Defter-i Hakani, Dahiliye, Hariciye)

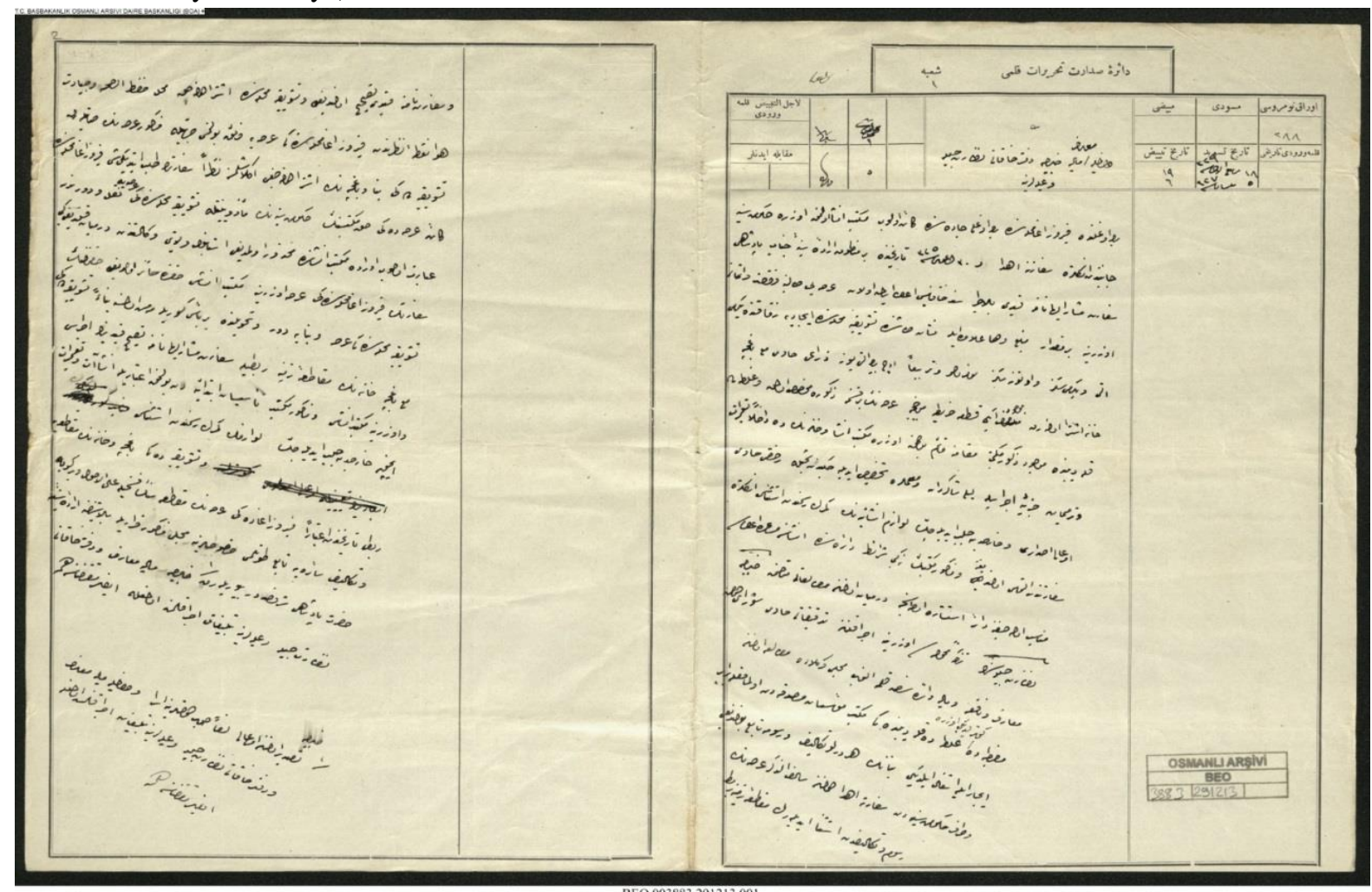

Ek. 2: Nişantaşı'nda Teşvikiye mahallesinin İcadiye sokağındaki İngiliz mektebi'nin inşası. (Maliye, Defter-i Hakani, Dahiliye, Hariciye) belgenin devamı

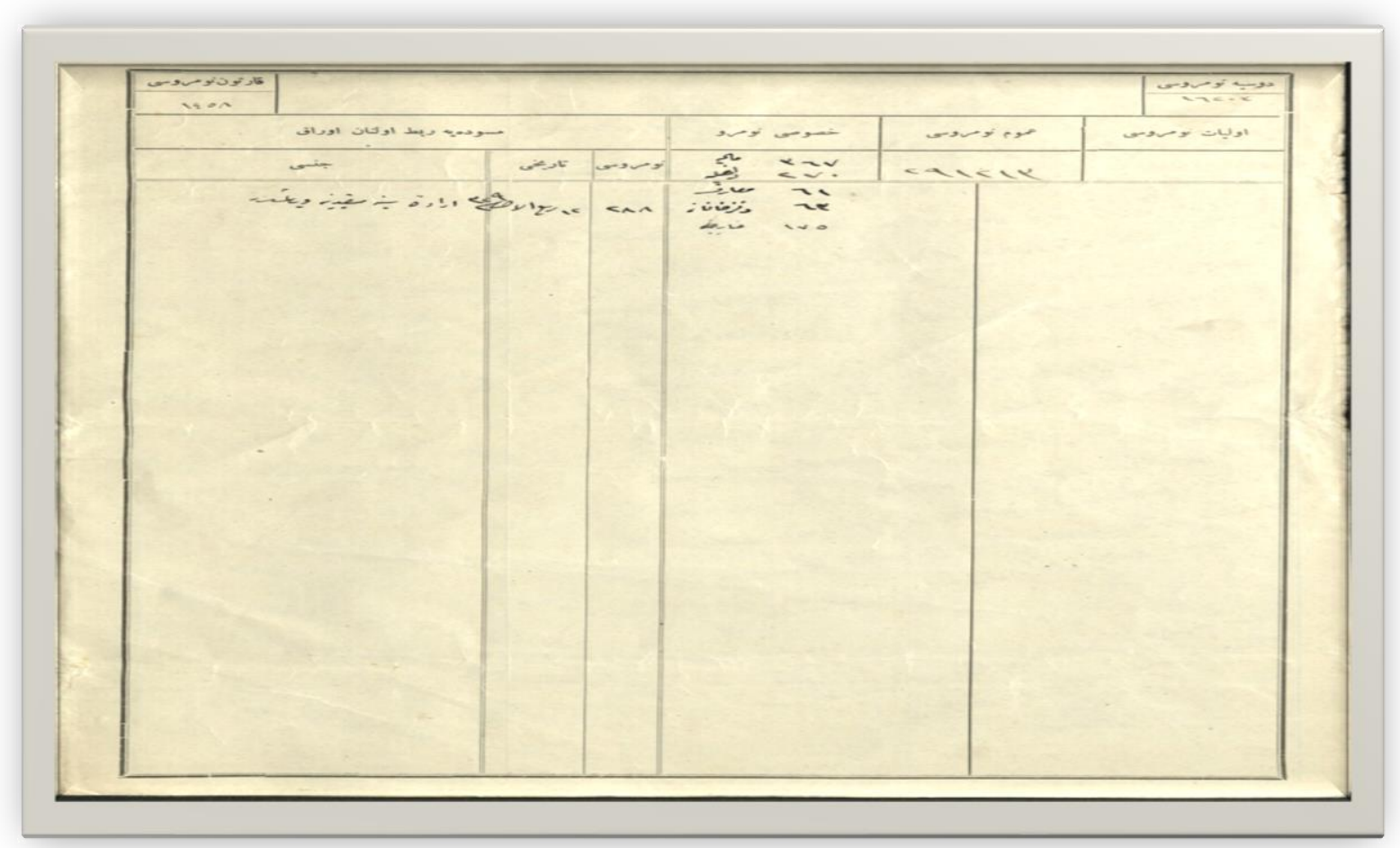

